\title{
History in Africa
}

\section{A JOURNAL OF METHOD}

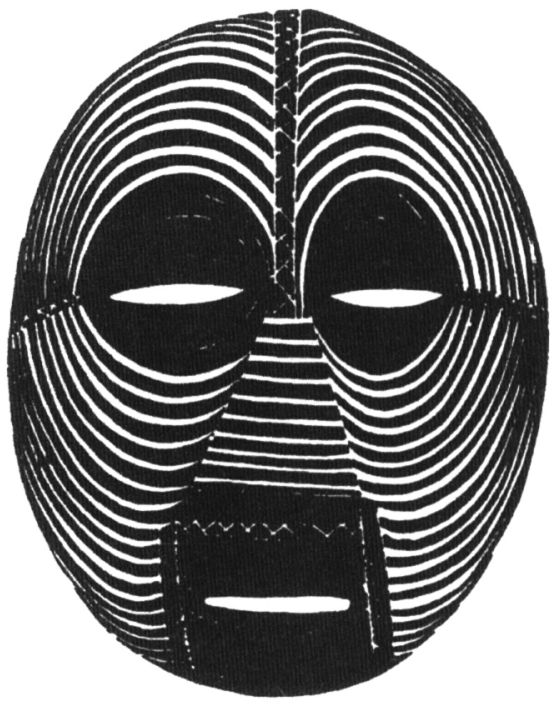

Published Annually by the AFRICAN STUDIES ASSOCIATION Vol. 37 / 2010 


\title{
HISTORY IN AFRICA A JOURNAL OF METHOD
}

\section{EDITORIAL BOARD}

\author{
D.C. Conrad
}

B. Fall Université Cheikh Anta Diop, Dakar

D. Henige University of Wisconsin-Madison

S. Jeppie University of Cape Town

A. Jones Universität Leipzig

R.C.C. Law University of Stirling/University of Liverpool

T.C. McCaskie University of Birmingham

J.C. Miller University of Virginia

I. Odotei University of Ghana, Legon

A. Olukoju University of Lagos

M. Twaddle University of London

$\mathbf{J}$. Vansina University of Wisconsin-Madison

\section{PRODUCTION MANAGER}

\section{J.C. Kaufmann University of Southern Mississippi}

History in Africa is published annually by the African Studies Association. Permission to reproduce materials from History in Africa should be obtained from the African Studies Association. Subscriptions and other business correspondence should be sent to the African Studies Association, Rutgers University-Livingston Campus, 54 Joyce Kilmer Ave., Piscataway, NJ 08854-8045 U.S.A. Tel: 732-445-8173 Fax: 732-445-1366 Website: www.africanstudies.org. Manuscripts and other editorial correspondence should be sent to Jan Jansen, Managing Editor, Pieter de la Court building, rm 3A36, Wassenaarseweg 52, 2333 AK Leiden, The Netherlands, Tel: (+31) (0) 715273996 , jansenj@fsw.leidenuniv.nl

Articles in History in Africa represent neither the views of the African Studies Association nor those of its officers. The editors are responsible for the final selection of the content of History in Africa and reserve the right to reject any material deemed inappropriate for publication. Responsibility for opinions expressed and for the accuracy of facts published rests solely with the individual authors. 


\title{
History in
}

\section{Africa}

\section{A JOURNAL OF METHOD}

\author{
EDITORS \\ Jan Jansen Leiden University, Managing Editor \\ Michel R. Doortmont University of Groningen \\ John H. Hanson Indiana University \\ Dmitri van den Bersselaar University of Liverpool
}

VOL. $37 / 2010$

\section{AFRICAN STUDIES ASSOCIATION}

Rutgers, The State University of New Jersey

Livingston Campus

54 Joyce Kilmer Avenue

Piscataway, NJ 08854-8045 U.S.A. 
ISSN 0361-5413

CCopyright 2010

\section{asa African Studies Association}

All rights reserved.

No part of this publication may be reproduced or transmitted in any form or by any means, including photocopy, recording, or any information storage and retrieval system, without permission in writing from the publisher. Any author has a right to republish his article in whole or in part without requesting permission from the Association; others desiring permission to republish material should write to the African Studies Association. 


\section{CONTENTS}

The Next Step for a Journal of Method

Michel R. Doortmont, John H. Hanson,

Jan Jansen, and Dmitri van den Bersselaar

\section{Critical Source Analysis}

Liberia and the Atlantic World in the Nineteenth

Century: Convergence and Effects

William E. Allen

Penser les intermédiaires coloniaux: Note sur

les dossiers de carrière de la police du Togo

Joël Glasman

"May It Please Your Honor": Letters of Petition as Historical Evidence in an African Colonial Context

Chima J. Korieh

Madiki Lemon, the "English Captain" at Ouidah, 1843-1852: an Exploration in Biography

Robin Law

Local Historians and Strangers with Big Eyes:

The Politics of Ewe History in Ghana

and Its Global Diaspora

Kate Skinner

$125-158$ 
"A Naughty Child with a Pen": Gahadzikwa Albert

Chaza as an African Policeman and Author in Colonial

Southern Rhodesia (Zimbabwe) 1936-1963

Tim Stapleton

African Girls' Samplers from Mission Schools in

Sierra Leone (1820s to 1840s)

Silke Strickrodt

Heritage, Tourism, and Slavery at Shimoni:

Narrative and Metanarrative on the East African Coast

Stephanie Wynne-Jones, and Martin Walsh

\section{Historiographical Reviews}

Sovereignty and Socialism in Tanzania:

The Historiography of an African State

Paul K. Bjerk

$275-319$

The Genesis and Evolution of the Ethiopian

Revolution and the Derg: A Note on Publications

by Participants in Events

Temesgen Gebeyehu

A History of the Rio Pongo:

Time for a New Appraisal?

Bruce L. Mouser

\section{Archive Reports}

Bold Research During Troubled Times in Guinea:

The Story of the Djibril Tamsir Niane Tape Archive

David C. Conrad

Finding Foreign Policy:

Researching in Five South African Archives

Matthew Graham 
Liberal Women in Rhodesia: A Report on

the Mitchell Papers, University of Cape Town

Kate Law

$389-398$

\section{Research Techniques and Education}

Potentials and Challenges in Oral Tradition Research and Education: Synchrotext Software

Peter Seitel

$399-416$ 